\title{
ENTREPRENEURIAL LEARNING IN THE CONTEXT OF FAILURE AND CREATION OF NEW BUSINESS
}

\author{
APRENDIZAGEM EMPREENDEDORA NO CONTEXTO \\ DE FRACASSO E CRIAÇÃO DE NOVOS NEGÓCIOS
}

Tania Regina Frota Vasconcellos Dias

Doutora em Administração pela Universidade Nove de Julho (São Paulo/Brasil).

Professora na Universidade Federal Rural do Rio de Janeiro (Seropédica/Brasil).

E-mail: trfvdias@gmail.com

\section{Cristina Dai Prá Martens}

Doutora em Administração pela Universidade Federal do Rio Grande do Sul (Porto Alegre/Brasil).

Professora na Universidade Nove de Julho (São Paulo/Brasil).

E-mail: cristinadpmartens@gmail.com

\section{Fabrício Martins Lacerda}

Doutor em Administração pela Universidade Nove de Julho (São Paulo/Brasil).

Professor na Universidade de São Paulo (São Paulo/Brasil).

E-mail: fabriciomlacerda@gmail.com 


\section{Brazilian

\section{ABSTRACT}

This research aims to describe the career and the entrepreneurial learning of micro-enterprises owners that identified new opportunities after the business failure. The methodology consists of a qualitative and exploratory study, with a cross-section approach and longitudinal perspective. Two entrepreneurs participated in the study, selected by convenience and availability, based on established criteria. Data collection was conducted through in-depth interviews, the interviews were recorded and transcribed. The dates were analyzed using content analysis. The study shows that new knowledge emerged from a learning journey in the context of business failure. It is learning about yourself, persistence, and resilience to succeed in new activities; about business and failure, flexibility to change the focus; on networks and relationships, as experience working with partners, employees and establish a network with the business partners; and on business management, to learn to minimize risks, because they understand that you must have a minimum knowledge of the market. During the development of new business, there is a predominance of exploration to transform the experience into entrepreneurial knowledge.

Keywords: Entrepreneurship. Entrepreneurial Learning. Business Failure. New Venture.

\section{RESUMO}

Esta pesquisa tem como objetivo descrever a carreira e o aprendizado empreendedor de proprietários de microempresas que identificaram novas oportunidades após o fracasso empresarial. A metodologia consiste em um estudo qualitativo e exploratório, com abordagem transversal e perspectiva longitudinal. Participaram do estudo dois empreendedores, selecionados por conveniência e disponibilidade, com base em critérios estabelecidos. A coleta de dados foi realizada por meio de entrevistas em profundidade, as entrevistas foram gravadas e transcritas. As datas foram analisadas por meio da análise de conteúdo. 0 estudo mostra que novos conhecimentos emergiram de uma jornada de aprendizagem no contexto do fracasso empresarial. É aprender sobre si mesmo, persistência e resiliência para ter sucesso em novas atividades; sobre negócios e fracasso, flexibilidade para mudar o foco; em redes e relacionamentos, como experiência em trabalhar com parceiros, funcionários e estabelecer uma rede com os parceiros de negócios; e na gestão empresarial, para aprender a minimizar riscos, pois entendem que é preciso ter um conhecimento mínimo do mercado. Durante o desenvolvimento de novos negócios, predomina a exploração para transformar a experiência em conhecimento empreendedor.

Palavras-chave: Empreendedorismo. Aprendizagem Empreendedora. Fracasso de negócios. Novo empreendimento. 


\section{Brazilian \\ Creative Industries}

\section{INTRODUCTION}

In the scenario of a globalized economy, interest in entrepreneurship is growing as a continuous learning process, as well as in the search for means that lead to greater productivity, competitiveness, and innovation (POLITIS, 2005, 2008).

According to the Brazilian Micro and Small Business Support Service [SEBRAE] (2014), micro and small businesses in the country (MSBs) represent more than half of formal jobs and are already the main generators of wealth in commerce, representing 53.4 \% of Gross Domestic Product (GDP). Studies, however, indicate that it is still possible to verify the existence of other important, but not so positive, aspects to be evaluated in the Brazilian business structure, such as the fact that they present high rates of failure (ALBUQUERQUE; ESCRIVÃO; CARVALHO, 2015; MINELLO; SCHERER, 2014). Research carried out with 221 Brazilian startups, published by Dom Cabral Foundation [FDC] (2014), focusing on the analysis of the entrepreneur, their characteristics, and their business environment reveals that $25 \%$ of these companies die before their first year of life, and half of them in less than four years. Part of the factors that lead businesses to failure are related both to the entrepreneur's life plan and to their behavior and business process (COPE, 2011; POLITIS; GABRIELSSON, 2009; SEBRAE, 2014), where experimentation, trial, and error are common strategies for dealing with uncertainty and ambiguity (SARASVATHY, 2001).

Failure can be an important source for the development of skills and knowledge for future endeavors (COPE, 2011; POLITIS, 2008, 2009; SHEPHERD, 2003; UCBASARAN; SHEPHERD; LOCKETT; LYON, 2013). It is a process where an entrepreneur's personal experience is transformed into knowledge, which in turn can be used to guide the choice of new opportunities (POLITIS, 2005). The experience arising from business failure represents the dynamic perspective of entrepreneurship, of what and how entrepreneurs learn, both personally and concerning business (COPE, 2011).

This context proposes a reflection on research that incorporates the entrepreneur's understanding of the learning process in the context of small businesses (BYGRAVE, 2010; HIGGINS; ASPINALL, 2011) and learning during the final phase of business life and its effects process (COPE, 2011; BLACKBURN; KOVALAINEN, 2009).

In this scenario, this research aims to describe the career and entrepreneurial learning of microenterprises owners that identified new opportunities after the business failure. Following this introduction, the second section addresses aspects related to entrepreneurship and entrepreneurial learning. The third section discusses the methodological procedures. In turn, the fourth section presents the analysis and discussion of the results and, finally, the final considerations. 


\section{Brazilian \\ Creative Industries}

\section{THEORETICAL FRAMEWORK}

\subsection{ENTREPRENEURSHIP AND BUSINESS CREATION}

Entrepreneurship comprises the process of identifying and exploring new opportunities. A more comprehensive approach to conceiving the nature of the entrepreneurial activity is provided by the behavioral perspective (SOUZA; GUIMARÃES, 2006). "The focus becomes the personal and organizational learning necessary for a person to adjust to changes in activities related to the entrepreneurial profession" (FILION, 1999, p. 11). The characteristics of entrepreneurs are linked to their respective historical contexts. Entrepreneurs are continually learning and developing their business about a broader environment (COPE, 2005). Research should focus on who through learning can become an entrepreneur (RAE; CARSWELL, 2000). The main objective of this perspective is to discern the entrepreneurial process, defined as one that involves the functions, activities, and actions associated with the perception of opportunities and the engagement in the creation of organizations (BYGRAVE, 2010).

"The perception that it is desirable to start a new company is a result of the culture, the subculture of a person's family, teachers and colleagues" (HISRICH; PETERS, 2004, p. 31). Some studies indicate that "childhood experiences and the family environment seem to make a difference, [...] they encouraged responsibility, initiative, and independence" (SCHERMERHORN, 2007, p. 126). According to Hisrich, Peters, and Shepherd (2014), most entrepreneurs indicate that their spouses are their biggest supporters and allow them to devote the enormous amount of time needed to the new venture. Stimuli are also given by professors and peers, who can significantly influence individuals to consider entrepreneurship a desirable and viable career. Several other factors contribute to the formation of a new company (HISRICH et al., 2014): a) the infrastructure provided by the government; b) formal education (schooling). Its importance is reflected not only in the educational level but also in the fact that it continues to play a role in helping entrepreneurs deal with the problems they face; c) age (chronological), most entrepreneurs start their careers between 22 and 45 years old; d) previous business experience and administrative skills. According to the authors, "[...] most entrepreneurs report that their most significant venture was not the first. [...] The experience of the previous initiative is a relatively good predictor for the start of subsequent companies [...]" (PETERS; SHEPHERD, 2014, p. 18); and e) the available financial resources.

In the view of Gartner (1985), the creation of a new business is a multidimensional phenomenon, which cannot be seen in isolation and involves four dimensions: a) the individual, with their knowledge, a key element for the creation of the new business and its features; b) the organization, regarding the type of organizational entity created, involving strategic choices and other market characteristics; c) the 


\section{Brazilian \\ Creative Industries}

environment, factors that encourage entrepreneurship, such as availability of capital, access to suppliers, access to consumers and new markets, government influences, among others; d) the process, when the entrepreneur perceives a business opportunity, accumulates resources, manufactures and sells products and services, builds the organization and responds to the government and society.

\subsection{ENTREPRENEURIAL LEARNING IN THE FACE OF BUSINESS FAILURE}

From the 1990s onwards, a new approach shifted attention to understanding entrepreneurship as a process characterized by significant critical learning events, as well as a continuous learning process (COPE, 2005, 2011; POLITIS, 2005, 2008).

Politis (2005) argues that literature and research suggest that much of the entrepreneur's knowledge of learning that takes place within a business context is experiential, which implies considering past experiences. For this author, career experiences in the entrepreneurial process comprise: a) experiences in business creation, the set of knowledge that led to new opportunities; b) experiences in management, problem-solving, decision making and; c) experiences in the specific sector (POLITIS, 2005). These, when put into practice, promote increased effectiveness in recognizing an opportunity, as well as dealing with the responsibility of the new business. However, the author highlights that the transformation of experience into knowledge, in turn, has two possible strategies in decision-making by entrepreneurs: Exploitation (they learn from experiences when exploring old certainties); Exploration (they learn by exploring new possibilities) (MARCH, 1991). This transformation process is influenced by: a) results of previous events, successful experiences (greater exploitative degree) or failures (greater explorative degree); b) logic or the dominant rationality: causation (uses analysis and estimation techniques to explore and exploitexisting and latent markets) or effectuation (does not start with pre-established goals, but follows those that emerge over time, according to aspirations and imagination of the entrepreneur) (SARASVATHY, 2001) and; c) career orientation regarding style: (i) linear, hierarchical progression within the company; (ii) specialist, long life in a specific occupation; (iii) spiral, movement of occupational areas and specialties; (iv) transitory, independence and challenges. The first two are characterized by the exploitative way of transforming experience into knowledge; the last two by explorative mode (BROUSSEAU; DRIVER; ENEROTH; LARSSON, 1996; POLITIS, 2005).

Business failure is seen as a complex process characterized by three interrelated phases in the learning process (COPE, 2011): a) reflection on the numerous costs of failure (financial, social, and psychological); b) critical reflection, a determined and conscious attempt to make sense of failure, with individual responses to failure and that can contribute to the development of future businesses (SHEPHERD, 2003) and; c) 


\section{Brazilian \\ Creative Industries}

reflexive action, period of action during which the entrepreneur tries to move forward with failure to seek other opportunities.

As a result, the entrepreneur develops a high level of learning (COPE, 2005, 2011): a) learning about himself, perceiving, understanding, and feeling about the world, making choices according to these new understandings (MEZIROW, 1991); b) learn about business and failure, understanding the processes and strategies that are employed within your organization (ARGYRIS; SCHÖN, 1978); c) learn about networks and relationships, develop social learning dynamic in the entrepreneurial process and; d) learn about business management (generative learning). Two approaches present themselves. The first is retrospective (adaptive), when the entrepreneur uses his experiential learning to reflect and, later, use it in future situations. The second, prospective (proactive), when the entrepreneur, by creating and anticipating experiences, instead of waiting for them, learned from them, by investing in new businesses before they had a total failure (GIBB, 1997; COPE, 2011).

\section{RESEARCH METHOD}

Based on the purpose of the research, a qualitative and exploratory study was chosen (RICHARDSON, 1999). Cases of failure are little explored, and, for this study, they will be understood as the discontinuity or death of the company for some reason, going beyond the relatively narrow conceptions of failure such as bankruptcy or liquidation (FERREIRA; OLIVA; SANTOS; GRISI; LIMA, 2012). The research is cross-sectional with a longitudinal perspective (VIEIRA, 2006). As for the selection of interviewees, Duarte (2012) reports that in qualitative studies this tends to be non-probabilistic, as its definition depends on the researcher's judgment and not on the drawing from the universe. Two entrepreneurs were selected for convenience; however, some criteria were established: that companies fit as micro-enterprises (ME), according to the number of employees (SEBRAE, 2015); that entrepreneurs act as owner-managers; and, that they have been unsuccessful and placed a new business. For this article, they were named "E1" and "E2".

The data collection procedure was carried out through an in-depth interview (MASSON, 1996). The recording of the interviews was carried out through direct recording, with the voluntary participation of the entrepreneurs and lasting approximately two hours.

For the treatment and analysis of the data, the method of content analysis was used, which consists of discovering the 'sense cores' that makeup communication and whose presence, or frequency of appearance, may mean something for the chosen analytical objective (BARDIN, 2011). By option of the researchers, it was preferred not to use software for textual analysis. The justification is given by the 


\section{Brazilian

importance and richness of the data obtained, and so that contact with the factual reality arising from the reports of the entrepreneurs would not be lost.

To make the research result more reliable and to establish a context between theory, method, and result (VIEIRA, 2006), the following steps were established for data analysis and interpretation: a) transcription and reading of the interviews; b) description of respondents by joining statements based on themes or categories that were described a priori; c) writing the analysis of the results, having the narrative as a foundation (JOVCHELOVITCH; BAUER, 2003) and; d) finally, data interpretation establishing relationships and discussion around the evidence generated from the interviewee's life trajectory and their entrepreneurial learning in the face of business failure.

It should be noted that, in this study, the testimonies given by the entrepreneurs were inserted in the body of work in the exact way in which their statements were made. The results of the research carried out will be discussed below.

\section{ANALYSIS OF RESULTS}

This section aims to analyze and discuss data from interviews conducted with the two entrepreneurs, to compare the set of explanatory models from the previously selected literature with data from the field research.

\subsection{THE CHARACTERIZATION OF ENTREPRENEURS AND BUSINESSES}

Figure 1 summarizes the characterization of the entrepreneurs who participated in the survey, businesses before the business failure, and new businesses. 


\section{Brazilian Creative Industries}

Figure 1. Characterization of entrepreneurs and their businesses

\begin{tabular}{|c|c|c|c|c|c|c|}
\hline 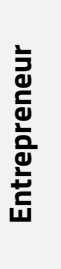 & 迹 & 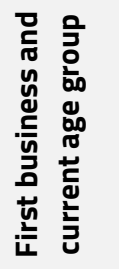 & $\frac{\substack{n \\
\frac{n}{n}}}{\frac{n}{\pi}}$ & $\begin{array}{l}\text { Education / courses } \\
\text { 1-before failure } \\
\text { 2-new business }\end{array}$ & $\begin{array}{l}\text { Businesses before the business } \\
\text { failure } \\
\text { (Location, number of employees } \\
\text { and partners) }\end{array}$ & $\begin{array}{c}\text { New business } \\
\text { (Location, number } \\
\text { of employees and } \\
\text { partners) }\end{array}$ \\
\hline E1 & $\frac{\frac{\omega}{\pi}}{\sum}$ & $\begin{array}{l}31-35 \\
41-55\end{array}$ & 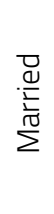 & $\begin{array}{l}\text { 1-Electronics Technician, } \\
\text { Technologist Graduated in } \\
\text { Management Processes; } \\
\text { 2-Graduating in } \\
\text { Administration }\end{array}$ & $\begin{array}{l}\text { 1- Equipment maintenance (Rio } \\
\text { de Janeiro) } \\
\text { ( } 2 \text { employees, } 1 \text { partner) } \\
\text { 2- Lighting trade (Rio de Janeiro) } \\
\text { ( } 3 \text { employees, } 1 \text { partner) }\end{array}$ & $\begin{array}{l}\text { Information technology } \\
\text { trade (Rio de Janeiro) } \\
\text { (4 employees, } 1 \text { partner) }\end{array}$ \\
\hline E2 & $\frac{\frac{\omega}{\pi}}{\sum}$ & $\begin{array}{l}20-24 \\
41-55\end{array}$ & 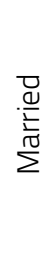 & $\begin{array}{l}\text { 1-Graduate in } \\
\text { Administration; } \\
\text { 2-Master in Education, } \\
\text { university professor }\end{array}$ & $\begin{array}{l}\text { 1- Consultancy and foreign trade } \\
\text { (São Paulo) } \\
\text { ( } 7 \text { employees, } 3 \text { partners) } \\
\text { 2- Import and distributor of } \\
\text { products (São Paulo) } \\
\text { (3 employees, } 1 \text { partner) }\end{array}$ & $\begin{array}{l}\text { Commercial } \\
\text { representation (São } \\
\text { Paulo) } \\
\text { (No employees, } 3 \\
\text { partners) }\end{array}$ \\
\hline
\end{tabular}

Source: Research data.

At the time they created their first businesses, the two entrepreneurs were aged between 20 and 40 years, which confirms the studies by Hisrich et al. (2014). Currently, they comprise the age group between 41 and 60 years, which confirms the influence of the professional career history in the decision to launch new businesses (Peters \& Shepherd, 2014) and demonstrates the professional experience in their areas of knowledge and the management of their companies. They also have a high level of formal education, an important circumstance for the development of the entrepreneur, as it plays a large role in helping them to deal with the problems they face in their business (Hisrich \& Peters, 2014).

\subsection{THE EXPERIENCES OF ENTREPRENEURIAL CAREERS UNTIL BUSINESS DISCONTINUITY (BUSINESS FAILURE)}

\subsubsection{Entrepreneur Experiences - E1}

I liked music and sometimes did little parties and, because of that, this ability, I decided to do a technical level in electronics [...] my parents, at the time, paid for the course at Colégio Martins, very good, and then I went to the Visconde de Mauá Technical School. [...] the course was excellent, [...] what I learned by practicing at home with the things I was already doing, I fixed something or another. 


\section{Brazilian \\ Creative Industries}

According to the entrepreneur, in the last year of the technical school, his first job opportunity arose, as he records: "[...] I went to do an electrical installation in a nightclub in Copacabana. [...] a colleague indicated it [...] and the owners of the house noticed my aptitude to deal with music, to be a DJ (at the time, a disco)". But he reports that he had difficulty in reconciling night work with study hours when he declared: "[...] I was about to graduate. So, I thank my parents [...] I believe few parents would allow this, but for me, at that moment, it was an opportunity". For E1 the work was particularly good, however, he registers: "[...] but the financial issue was very low, [...]". The entrepreneur resigned and as he reports: "[...] I ended up going to work in a club. [...] I was also a disco, but I only worked on Sundays, so I could go back to school, and so I did".

Other job opportunities appeared when the entrepreneur finished technical school, however, these were not successful. The following year, at the end of the course, in 1982/1983, he registers a new phase in his life.

\footnotetext{
[...] I got the yellow pages, it was there, electronics, right in the first few letters there was a company called Borrows, (today Unisys) a big company [...] it was a very difficult process, there were only 10 vacancies and I passed. [...] we had training. We went to the factory to work with assembly and disassembly of equipment, and, at the end of the internship, I was hired as a trainee, and stayed in this company for three years as a technician. When I decided to leave, I said to myself: I'm an entrepreneur, I'm very restless, I don't accept obeying.
}

Around 1986, the entrepreneur sought another opportunity, now at Medidata, as he registers: "[...] a company that was also large at the time, specialized in the IT area, [...] after a year in the company I started to being a supervisor at the Rio branch [...] maintenance of minicomputers and supermicros, which was what I had at the time".

\section{The intention to create the first businesses: influence from friends, family, and their entrepreneurial characteristics.}

There is a real rupture in the entrepreneur's reality due to the maturation that occurred in his professional life. Thus, while still working at the Medidata company, the interviewee and a colleague had a common interest, related to organizing parties and events. Thus, said the entrepreneur: "We partnered with a restaurant (Elefante Branco, in the suburb of Rio), to have a party on Wednesday [...] because the restaurant, from Thursday to Sunday (live music, with guitar and voice) already had movement, they already had clients". He reports that a Wednesday's earnings represented the entire month's salary at Medidata, he said: "I ended up leaving Medidata, to run this business. [...] I agreed with my partner, he 


\section{Brazilian \\ Creative Industries}

would continue working at Medidata, [...] and I left". And he explains: "[...] because these events, something I've done throughout my life, in parallel, they make money. [...] from there we ended up going to a club, to a bigger place in Bonsucesso, where we weren't as successful as in this house, but we stayed for a while". Parallel to this business, the entrepreneur said: "[...] we also started to make professional signage, to have parties, we had big shows: the beach volleyball world championship in Ipanema, we did work for the radio $[\ldots] "$.

When it comes to creating a new company, Filion (1999, p. 10) reports that "[...] people are more likely to become entrepreneurs if there is a model in the family or their environment". Other authors, such as Bohnenberger, Schmidt, and Freitas (2007) and Teixeira, Ducci, NPC, Sarrassini, Munhë and Ducci, LZ (2011), report the importance of family members when they contribute to the entrepreneur's success in all phases of the business. characterized as facilitators and motivators, as was the case with this respondent, as his parents have always supported him since the beginning of his career. And then, as he recorded: "[...] I had uncles who had communication businesses, telephone installation and so on. [...] and I worked with them for a few months, as a freelance, and did ambient sound installations".

During the interview, it was observed that $\mathrm{E} 1$ has a personality with entrepreneurial characteristics, such as: a) high energy level, with the fact that she cannot support self-indulgence; b) self-confidence and a yearning for independence, for wanting to be your boss, as I said: "[...] I'm an entrepreneur, I'm very restless, I don't accept to obey" and; c) high need for achievement, for being focused on always doing what he likes (working with electronics, sound, disco), challenging himself and; d) tolerance for ambiguity, as it does not mind taking risks in creating new businesses.

\section{Formal businesses: Startpoint and Mega Lux companies}

The entrepreneur reports:

[...] at Elefante Branco we started, but there was no formalized company, but it was already our own business in some way, $[. .$.$] there came a time when we were working$ with lighting, an area that was called robotics, with engines, crazy ball, and this type of equipment, and I realized [...] that we did maintenance on our equipment and that there was no one in Rio who did that. [...] we saw this as an opportunity, and we thought: why don't we take it to do maintenance on this? [...] we managed to get authorization from several manufacturers, mainly lighting, [...] and we partnered with the stores that sold in Rio, to recommend us and, we constituted a company. We rented a room, my partner and $I$, and set up a company, Starpoint, maintenance of lighting and sound equipment. (Our italics) 


\section{Brazilian \\ Creative Industries}

As for the second business, the entrepreneur highlights the circumstances in which the company was formalized.

[...] We thought that more profit would come from selling equipment, but we had partnerships with several stores, [...] it would generate a conflict with these partners because they indicated the customer to us. [...] so we decided to set up another company that only sells lighting equipment for nightclubs and such. [... we rented a store, had contact with the equipment manufacturer, set up a showroom, and we called this company Mega Lux, which was lighting, and it was a success, we managed to create a differential, which I always tried to work with service, with quality, and we made projects. (Our italics)

When analyzing the entrepreneurial career experience for the creation of the first formal businesses, it was observed that E1 presents: a) experience in business creation, due to internships carried out during the technical school, in electronics, entertainment and, also, for the placement of informal businesses related to the maintenance of electronic equipment, given that he also worked in a computer company. The respondent also presented a model of conduct of the uncles who had their own business, including having worked with one of them in electronics; b) experience in managing their informal businesses: as an instructor, salesperson in the companies where he worked in the execution of jobs in the electronics and computing area; c) experience in the specific sector, more precisely in electronics and computing. There is also the influence of friends and the support of his family in this entrepreneurial career.

\section{Separation from society, financial difficulties, and closing the business}

As the entrepreneur records about society: "[...] I was always more audacious, I invested more, in short, and he was always more afraid. [...] And we separated society [...]". Given his business, financial problems proved to be a major obstacle in the entrepreneur's management, as he reports: "[...] the default rate I had in this company was very high because I didn't have capital, in fact, we never had the capital to get and invest, and I think this is the big problem of the small entrepreneur because he has the will, he wants to undertake, but he has no financial resources, and often he depends on that money to survive, to pay the accounts, so this is complicated. [...] there came a time when I realized that I couldn't continue, and [...] so I decided to close the company (Mega Lux)". 


\title{
Brazilian \\ Creative Industries
}

\subsubsection{Entrepreneur Experiences - E2}

\begin{abstract}
Since I was a child I had entrepreneurial ideas, [...] I bought and sold birds, bought and sold horses, I always bought and sold something. I needed change, I didn't have an allowance, I couldn't do things, so I had to use my intelligence to make money. My entrepreneur was already there, kind of jumping.
\end{abstract}

For the entrepreneur, during his graduation in Business Administration at Fundação Getúlio Vargas (FGV), already in the first six months of the course, he would have been awakened to an entrepreneurial attitude, at the time his economics professor requested the realization of a certain work.

You choose the business you want to develop and talk about [...]. I talked about ironwork (working with horse ironwork), I liked it, [...] I was always in love with horses. I looked for information, and I was the first Brazilian to go to the United States to learn how to shoe horses. [...] it even became a business, a provision of services [...].

During his undergraduate course, he had several jobs, according to: "[...] trainee in organizations and methods [...] in international transport at A\&M, a holding company, in Germany [...] bank (Citibank). [...] With college at night, [...] working all day, he worked in parallel with the hoofing of horses". According to the entrepreneur, he acquired knowledge and experience in administrative functions, as he reports: "[...] credit analysis, sales, and product management. [...] I developed export developers and took care of all export traffic, [...] buying from a seller in Cape Verde, Africa".

\section{The intention of creating the first businesses: a society with friends, difficulties, and acquired experiences}

Said the entrepreneur:

[...] in 1991, I was in trading (commercial area) until I graduated. When I graduated I joined a trainee program at Cargio. I was chosen for an area that later I found out that the area was being closed down, there I was, desperate [...] together with 3 friends, we set up a consulting company in foreign trade. [...] we set up Mercor, in 1991. [...] (our italics)

As reported in the interview, the company was formed by four young partners (one lawyer and three former FGV graduates), undercapitalized. And he said: "an operation to export auto parts for trucks, [...] we started to pursue and develop this market, the product was sold here in Brazil for 17 or 18 years until 


\section{Brazilian

today it is a reality, it is a trailer mileage controller". According to the entrepreneur, there was a great deal of learning and experience in management:

[...] which suffered a lot to introduce into the country, to sell, to fix the methodology, how to approach transport companies. And then we suffered from seasonality, policies, import licensing. It was the opening phase, of the government [...]. There was the question of exchange rate variation. That was suffering, we learned to be beaten. (our italics)

As we have seen, the entrepreneur in this study has experiences with business management and in the specific sector, given the influence of his undergraduate professor and his family members because, as I said: "[...] all my entrepreneurial initiatives they were always supported by my family". This reinforces research that concludes with the importance of family influence in all phases of the business for success (Teixeira et al., 2011) and that people are more likely to become entrepreneurs if there is a model in the family or its environment (Filion, 1999). The entrepreneur said: "My grandparents on the mother's side were already entrepreneurs, my grandfather had a business, he was Swiss and had a business in the Belgian Congo, and then he came to Brazil and opened his business here. On the other side of my family [...] my grandmother, after the war, had a pension that received Germans who were moving to Brazil [...]".

For the respondent: "[...] experience generates competence for you to work with this business in the future. [...] because I worked with imports, it made life easier for me. The reason that allowed me to join a partnership, I had a certain knowledge with my partners". He then reports that he decided to leave the business and would have gone back to being an employee until a great idea came along. According to the entrepreneur: "I sold the share of the result, 'an umbrella for four does not protect from the rain'. [...] it was a loss. [...] I was once again employed in foreign trade, a large trading company. [...] with difficulty because I take risks, I have attitude [...]".

In the development of the E2 interview, the presence of several entrepreneurial characteristics is verified, such as: a) high need for achievement, when she declares: "[...] my entrepreneur was already there, kind of jumping [...]"; b) tolerance for ambiguity, when taking risks and withstanding situations with a high degree of uncertainty; c) self-esteem, when he decided to start the business, believing in himself; d) self-confidence and a yearning for independence, as he wants to be his boss, believes he is in control of his destiny. 


\section{Brazilian Creative Industries}

\section{Second deal: difficulties in the market for your product and closure}

In this new phase, the entrepreneur presents previous experiences in business creation and management practice. He is driven by passion and action when developing a technology to produce his product. And in the specific sector (foreign trade).

[...] as I had already hulled, shoeed horses, I came up with the idea of holding nails for horseshoes, and special aluminum shoes for high-performance sports horses, and I knew import and export. I put my hand in my pocket and said, I'm going to go. It was a thing I spent a good part of my life doing, and I stopped playing because it had serious competition problems and, again, I had to reinvent myself as a professional. I started to import and export products from California and Australia, with all the difficulties in foreign trade, in forecasting demand, difficulties that microentrepreneurs have, it still worked very well. (Our italics)

The entrepreneur reports an outburst: "[...] it is not possible for a product that has existed since the times of Rome [...] to withstand long journeys, so after six years I managed to produce a harpsichord that had quality, but that I couldn't produce in quantity and economic scale, and that was my breaker [...]".

\subsection{THE PHASE OF DISCONTINUITY AND THE LEARNING JOURNEY}

To achieve the objective of this study, the data collected in the interviews carried out with the two entrepreneurs will be grouped and analyzed together.

\section{Entrepreneur E1}

Reflecting on the discontinuity of his business and the start of a new one, he said, "Well, this isn't working, I'm going to take a break". But, according to him, it was not stagnant, as it appears:

I had some products at home, computer, electronics, and such, and I thought about selling them because they were making volume at home, and at the time I put them on the internet to sell, on an auction site, and to my surprise, I put them up and sold them. [...] so I was studying a computer segment, which is 2003 , was still starting, wireless network equipment, so I started working with routers, the thing started to grow, I started to have suppliers who came to me offering products to work with another line of external wireless networks. [...] I set up an online store, Wireless Cia., and made a sales website. (Our italics) 


\section{Brazilian

\section{Entrepreneur E2}

When reflecting on the discontinuity, due to the closure of his business, the entrepreneur experienced professional reflexes, as he made a point of recording:

[...] as I was an entrepreneur for a long time, what happens, you can't go back as an employee. [...] I went to work on this CELEX that [...] was not earning much, I was completely disrespected in everything, at a stage where I had to ask for God's love. [...] but, within this project, [...] / developed a relationship with universities, I started teaching [...] I was even sent away from the project. [...] and today, in this crash, I reinvented myself as a teacher. (Our italics)

In this scenario of adversity, the entrepreneur is driven by action, by a behavioral attitude, which aimed to establish a new business. The entrepreneur said: "[...] so I was already a teacher, [...], and my fixed cost was guaranteed [...]" and he declared: "[...] and now how am I going to do the variable gain, I want to do it without risk because I didn't have more money to bet". In this way, he saw the possibility of developing a portfolio of companies. A commercial representation activity, Promopack. The entrepreneur said: "[...] me and a childhood colleague, we developed some factories that needed commercial representation, and we have the experience of the 'business to business' business [...]".

At this point, it is important to highlight a common characteristic of the two entrepreneurs, flexibility. Entrepreneurs are ready to admit their mistakes and problems, as well as change the course of action when plans are not working out (Hisrich \& Peters, 2004). Entrepreneurs have always been guided by passion and action, anticipating problems in such a way that their lives could move forward without temporal obstacles. Therefore, it is observed, by the reports, that the "time" needed to recover from the pain and trauma generated by failures was not formalized, as stated by Cope (2011). This "time" was replaced by other investments, sometimes in charge of their formal and informal businesses, sometimes as an employee of some company. This "forward" behavior with failure to seek other opportunities is a feature of the third phase of the learning journey, reflective action. In this sense, we sought to describe the other phases of the learning journey: reflection on the costs of failure and critical reflection, to understand the entrepreneur's learning for the development of their future business.

\section{Reflection on the costs of failure: financial, social, and psychological}

Regarding the financial costs, it appears that the two interviewees, even if in different degrees, had a certain kind of loss. Reflecting on the costs of failure, E1 states: "[...] there came a time when I couldn't 


\section{Brazilian \\ Creative Industries}

pay, my commitment to the bank. And I decided to close, just the physical part, the store, and changed the company's focus to work only with projects and sales to companies and such, and this company is still working today." Now E2 registers: "[...] I broke, I had no more conditions, I didn't have any more money in my pocket, I didn't have money to buy cigarettes, it was just my house and that's it [...]". As for costs, social and psychological, the entrepreneurs said they had gone through difficult times. As E1 states: "[...] I had to adapt, between being an entrepreneur and working as a professional in a company because we have to survive, so it's no use saying: I'm going to be an entrepreneur forever, everyone has a bit of I'm afraid, anyway". Thus, to have better job placement, the entrepreneur registers: "[...] I sought to do a higher education course, as I had no conditions at the time, [...] I sought a public college. I took the social pre-university entrance exam, took the entrance exam three times for Administration, and, the third time, I passed. [...]". The entrepreneur also said: "Last year, in 2013, as I had done some graduations [...] and had some credits, I got it at Estácio de Sá [...] and at the end of 2013 I graduated as a technologist in management processes". For E2, the costs brought professional reflexes, as the entrepreneur declares: "[...] the first thing, when you go broke, this failure, you become a loser. [...] you are very discredited. Family, friends, friends don't charge, but family members are like that horror show".

\section{Critical reflection (sensemaking)}

Survey participants, during their interviews, when reflecting on the moment of closing their business, sought to make sense of failure. According to entrepreneur E1: "One characteristic I have and am proud of is emotional resistance and perseverance. I had, [... at times, I won't say that it never happened to me, but if it happened, like one day it happened, the next day it's already rolled up". For him, the failure in an enterprise: "[...] is a stage that didn't work out, but you can redo it or try to do it differently, I think it's important for you to face it". And he stated: "[...] I think you learn more from failure than from success". For entrepreneur E2, the bankruptcy of a company results in an imbalance in the family environment, and he says that he teaches his students. Said the entrepreneur: "It was a learning experience for me, how do you break the company as a micro-entrepreneur without breaking the family? Because the guy being a businessman is very associated [...] only a very large businessman can think about it and organize himself so as not to break the company and break the Family". According to the entrepreneur: "[...] I consider both success and failure as a way of learning". The entrepreneur said about the failure: "It's because you haven't reached your planned goal".

At this stage, social interaction is important, as entrepreneurs can seek support from family, friends (Shepherd, 2003), as stated by E1, "[...] you cannot remain passive, you [...] must have flexibility even for, 


\section{Brazilian \\ Creative Industries}

for example, in my case (family, wife) there were times when my family had access to health insurance, my children studied in private school. At another time, the school was public, and we used the Unified Health System, anyway". And as was the case with E2, when in her previous statement she evidenced the support of friends during her employment at CELEX, by developing her network of contacts with professors and expanding her relationship with universities.

\subsection{ENTREPRENEURIAL LEARNING IN THE FACE OF BUSINESS FAILURE}

During the interview of the entrepreneurs, the presence, in their statements, of the two dominant forms of logic or rationality (causation and effectuation) is verified. In this sense, interviewee E1 said: "[...] I realized this in time, and I was changing the focus and I was adapting, according to the market. You have to always be on the lookout for what's going on, what's going to happen." And interviewee E2 says: "You must develop a Network, [...] a commercial sensitivity [...], this commercial representation portfolio is a living portfolio, and you have to treat it as such because if you don't, you won't attract new customers. [...]. This is portfolio risk management".

During the entrepreneurial process and given career characteristics and motivations, entrepreneurs sought different types of events and learning situations.

The interviewee E1, for developing his professional career moving in occupational and specialty areas, given his specific knowledge of the computer and electronics sector, with creativity and personal development, the entrepreneur presents characteristics of spiral career orientation. However, due to the independence that he always displayed throughout his professional career, as, according to previous statements, he resigned, he also carries a transitory career style. For respondent E2, it appears that the entrepreneur also has a mix of style, due to his two occupations: specialist career guidance, as a teacher, who is still developing, improving his knowledge within this specialty (preparing for the doctorate), with this, it seeks achievement, prestige regarding motivation; spiral, managing partner/salesman, the position he occupies today at the head of his current business.

In these terms, the two entrepreneurs focus more broadly on an explorative way of transforming experience into knowledge (BROSSEAU et al., 1996).

During this learning journey, which, according to Cope (2005, 2011), can stimulate different forms of high-level learning, fundamental for entrepreneurs, both in personal and business terms, the presence of the four forms of learning in the failure summarized below, in Figure 2, with the declarations of the entrepreneurs. 


\section{Brazilian \\ Creative Industries}

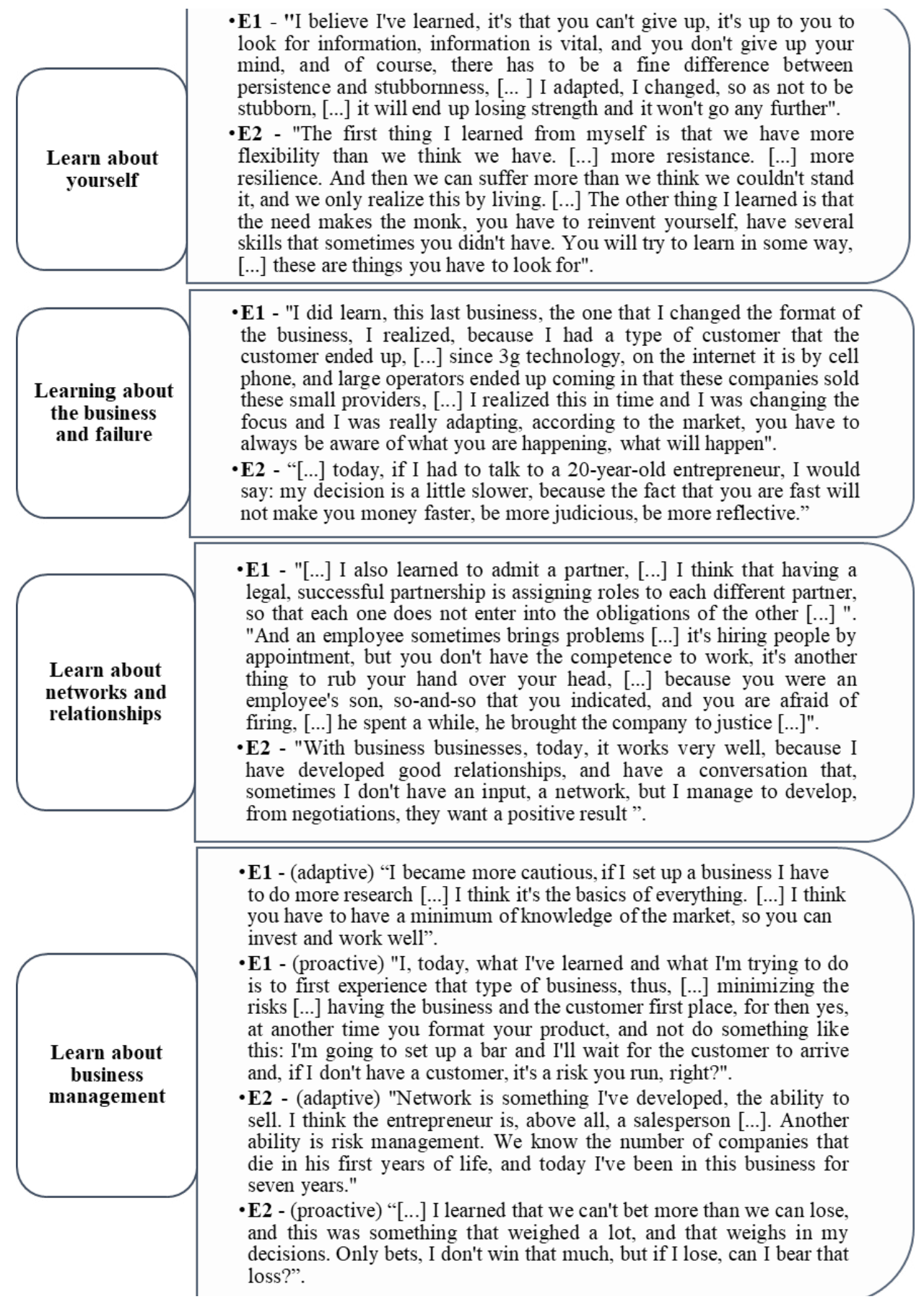

Figure 2. Learning dimension of entrepreneurs in the face of failure Source: Research data. 


\section{Brazilian

\section{FINAL CONSIDERATIONS}

Given the various challenges faced by the entrepreneurs in this study, there is an identity between the individual and the legal entity, as the individual and his business are highly intertwined (owner and manager).

This paper records the results of research produced to describe the trajectory and entrepreneurial learning of micro-enterprise owner-managers who identified new opportunities in the face of business failure. From the life story narrated by these entrepreneurs, it was observed a set of experiences that contributed to the understanding of how they learned from business failure. By revealing how they learned about themselves, they demonstrated the importance of persistence and resilience to succeed in new endeavors. About the business and failure, both have the flexibility to change focus, adapt, be more judicious about risks. On networks and relationships, they gained experience in working with partners, employees and establishing a network with their business partners. About business management, they learned to minimize risks, as they understand that it is necessary to have a minimum knowledge of the market.

During the development of new businesses, their statements show how to transform experience into entrepreneurial knowledge, a predominance of exploration. According to E1: "[...] entrepreneurship is innovation. I have an opportunity now that it came, to work with another segment, so it comes, and I'm in, I'm always tuned in [...]". The E2 says: "[...] I like the new, the new projects are way better than dealing with the old ones. [...] I wanted to set up a company and close it in two years, to set up another and so on".

The results found in this study should be interpreted exclusively concerning the interviewed entrepreneurs. New knowledge can emerge, as learning is a dynamic and continuous process, changing in the light of new experiences.

For future studies, it is suggested the replication of this research with a larger number of entrepreneurs, to verify the relevance of the results.

\section{REFERENCES}

ALBUQUERQUE, A. F.; ESCRIVÃO FILHO, E.; CARVALHO, K. C. Os fatores ambientais e a mortalidade da pequena empresa: descrição dos fatores relevantes no setor de varejo de vestuário. In: Encontro Nacional da Associação Nacional de Pós-Graduação e Pesquisa em Administração. Anais... Belo Horizonte, MG, Brasil, setembro 2015. 


\section{Brazilian Creative Industries}

ARGYRIS, C.; SCHÖN, D. A. Organizational Learning: a theory of action perspective. Reading, MA: Addison-Wesley Publishing CO., 1978.

BARDIN, L. Análise de Conteúdo. 1. ed. 3a. reimp. Lisboa: Edições 70, 2011.

BOHNENBERGER, M. C.; SCHMIDT, S.; FREITAS, C. A influência da família na formação empreendedora. XXXI ENANPAD. Anais... 2007.

BROUSSEAU, K. R.; DRIVER, J. M.; ENEROTH, C.; LARSSON, R. Career pandemonium: realigning organizations and individuals. Academy of Management Executive, 10 (4), 52-66. 1996.

BLACKBURN, R.; KOVALAINEN, A. Researching small firms and entrepreneurship: past, present and future. International Journal of Management Reviews, 11 (2), 127-148. 2009.

BYGRAVE, W. D. The Entrepreneurial process. In: BYGRAVE, W. B.; ZACHARAKIS, A. (Eds.). The Portable MBA in Entrepreneurship. 4. ed. Hoboken, NJ: John Wiley \& Sons, 2010.

COPE, J. Toward a dynamic Learning Perspective of Entrepreneurship. Entrepreneurship, Theory and Practice, 29 (4), 373-397. 2005.

$\mathrm{COPE}, \mathrm{J}$. Entrepreneurial learning from failure: an interpretative phenomenological analysis. Journal of business Venturing, 26 (6), 604-623. 2011.

DUARTE, J. Entrevista em profundidade. In: DUARTE, J.; BARROS, A. (Orgs.). Métodos e técnicas de pesquisa em comunicação. São Paulo: Atlas, 2012.

FERREIRA, L. F. F.; OLIVA, F. L.; SANTOS, S. A. dos; GRISI, C. C. H. de; LIMA, A. C. Análise quantitativa sobre a mortalidade precoce de micro e pequenas empresas da cidade de São Paulo. Gestão e Produção, 19 (4), 811-823. 2012.

FILION, L. J. Empreendedorismo: empreendedores e proprietários-gerentes de pequenos negócios. Revista de Administração, São Paulo, 34 (2), 5-28. 1999.

FUNDAÇÃO DOM CABRAL. Causas da mortalidade de startups brasileiras: 0 que fazer para aumentar as chances de sobrevivência no mercado? (Núcleo FDC de Inovação e Empreendedorismo). Belo Horizonte: Autores. 2014. Recuperado em 10 abril, 2016, de https://www.fdc.org.br/blogespacodialogo/Documents/2014/causas_mortalidade_startups_brasileiras.pdf.

GARTNER, W. B. A conceptual framework for describing the phenomenon of new venture creation. Academy of Management Review, 10 (4), 696-706. 1985. 


\section{Brazilian Creative Industries}

GIBB, A. A. Small firms' training and competitiveness: building on the small business as a learning organization. International Small Business Journal, 15 (3), 13-29. 1997.

HIGGINS, D.; ASPINALL, C. Learning to learn: a case for developing small firm owner/managers. Journal of Small Business and Enterprise Development, 18 (1), 43-57. 2011.

HISRICH, R. D.; PETERS, M. P. Empreendedorismo. 5. ed. Porto Alegre: Bookman, 2004.

HISRICH, R. D.; PETERS, M. P.; SHEPHERD, D. A. Empreendedorismo. 9. ed. Porto Alegre: AMGH Editora Ltda., 2014.

JOVCHELOVITCH, S.; BAUER, M. W. Entrevista narrative. In: Bauer, M. W.; Gaskell, G. Pesquisa qualitativa com texto, imagem e som: um manual prático. 2. ed. Petrópolis: Vozes, 2003.

MASON, J. Qualitative researching. Thousand Oaks, California: Sage. 1996.

MARCH, J. Exploration and exploitation in organizational learning. Organization Science, 2 (1), 71-87. 1991.

MEZIROW, J. Learning as Transformative dimensions of adult learning. San Francisco, CA: Jossey-Bass, 1991.

MNELLO, I. F.; SCHERER, L. A. Comportamento e tipologia do empreendedor diante do insucesso empresarial. Sociais e Humanas, 27 (1), 81-101. 2014.

MINNITI, M.; BYGRAVE, W. A dynamic model of entrepreneurial learning. Entrepreneurship Theory and Practice, 25 (3), 5-16. 2001.

POLITIS, D. The Process of Entrepreneurial Learning: A Conceptual Framework. Entrepreneurship, Theory and Practice, 29 (4), 399-424. 2005.

POLITIS, D. Does prior start-up experience matter for entrepreneurs' learning? A comparison between novice and habitual entrepreneurs. Journal of Small Business and Enterprise Development, 15 (3), 472-489. 2008.

POLITIS, D.; GABRIELSSON, J. Entrepreneurs'attitudes towards failure: an experiential learning approach. International Journal of Entrepreneurial Behaviour \& Research, 15 (4), 364-383. 2009. 


\section{Brazilian Creative Industries}

RAE, D., CARSWELL, M. Using a life-story approach in researching entrepreneurial learning: The development of a conceptual model and its implications in the design of learning experiences. Education \& Training, 42 (4/5) 220-227. 2000.

RICHARDSON, R. J. Pesquisa Social: métodos e técnicas. 3. ed. São Paulo: Atlas S. A., 1999.

SARASVATHY, S. D. Causation and effectuation: Toward a theoretical shift from economic inevitability to entrepreneurial contingency. Academy of Management Review, 26 (2) 243-288. 2001.

SEBRAE. Serviço Brasileiro de Apoio às Micro e Pequenas Empresas. Causa mortis: o sucesso e o fracasso das empresas nos primeiros 5 anos de vida. São Paulo: Autores, 2014 Recuperado em: 12 agosto, 2012, de http://www.sebraesp.com.br/arquivos_site/biblioteca/EstudosPesquisas/mortalidade/causa_mortis_2014.pdf.

SEBRAE. Serviço Brasileiro de Apoio às Micro e Pequenas Empresas. Anuário do trabalho na micro e pequena empresa 2014. (Departamento Intersindical de Estatística e Estudos Socioeconômicos, responsável pela elaboração da pesquisa, dos textos, tabelas, gráficos e mapas). 7. ed. São Paulo: Organizadores, 2015. Recuperado em: 12 agosto, 2016, de

http://www.sebrae.com.br/Sebrae/Portal\%20Sebrae/Anexos/Anuario-do\%20trabalho-na\%20micro-e-pequena\%20empresa-2014.pdf.

SCHERMERHORN, Jr. J. R. Administração. 8. ed. Rio de Janeiro: LTC, 2007.

SHEPHERD, D. A. Learning from business failure: propositions of grief recovery for the self-employed. Academy of Management Review, 28 (2), 318-328. 2003.

SOUZA, E. C. L. Empreendedorismo da gênese à contemporaneidade. In: E. C. L. SOUZA; T. A. GUIMARÃES (Org.). Empreendedorismo além do plano de negócio. São Paulo: Atlas, 2006, pp. 3-20.

TEIXEIRA, R. M.; DUCCI, N. P. C.; SARRASSINI, N. S.; MUNHÊ, V. P. C.; DUCCI, L. Z. Empreendedorismo jovem e a influência da família: a história de vida de uma empreendedora de sucesso. Revista de Gestão - REGE, São Paulo, 18 (1), 3-18. 2011.

UCBASARAN, D.; SHEPHERD, D. A.; LOCKETT, A.; LYON, J. Life after business failure: the process and consequences of business failure for entrepreneurs. Journal of Management, 39 (1), 163-202. 2013.

VIEIRA, M. M. F. Por uma Boa Pesquisa (Qualitativa) em Administração. In: VIEIRA, M. M. F.; ZOUAIN; D. M. (Org.). Pesquisa Qualitativa em Administração. 2. ed., p. 13-28. Rio de Janeiro: FGV, 2006. 